\title{
PECULIARITIES OF GRANTING EMPLOYMENT LEAVE IN CASE OF SARS-COV-2 INFECTION UNDER ROMANIAN REGULATION. LESSONS FOR THE FUTURE*
}

\author{
Sorin-Alexandru VERNEA**
}

\begin{abstract}
Through this paper, the author analyzes the nature of medical leave granted under the conditions of Emergency Ordinance no. 158/2005 on leave and social health insurance benefits and under Law no. 136/2020 on the establishment of measures in the field of public health at epidemiological and biological risk. The paper is divided into two sections, the first aimed at identifying the nature of medical leave as regulated in Romanian legislation, and the second following the particularities of medical leave granted in case of infection with Sars-CoV-2. Finally, brief conclusions were drawn regarding the reliability of the regulatory framework regarding medical leave for quarantine or isolation.

Keywords: sick leave; Covid-19 infection; inability to work; epidemiological risk; health protection
\end{abstract}

DOI: 10.53373 / REDS.2021.52.3.025

\section{Introduction}

The last year has marked a long series of radical changes in the functioning of society, both nationally and internationally. With the declaration of the Covid-19 pandemic on 11.03.2020, most countries have taken alert measures to protect the population against infection, at the cost of large social and economic changes.

In Romania, the establishment of state of emergency by the Decrees of the President no. 195/16.03.2020 and no.240/14.04.2020 ${ }^{2}$ led to a restriction of activities in both the public and private sectors, which directly affected the labor market.

Considering the evolution of epidemiological situations, the legislator has adopted a relatively functional regulatory framework designed to provide support to the population against epidemiological risk, including a series of regulations on the granting of medical leave for insured persons, found in temporary incapacity to work due to personal quarantine or measure of isolation.

During this period health surveillance has become an essential element in the organization of any economic activity, and the current national regulations, namely

\footnotetext{
* Paper presented at the International Conference "The future of labor law after coronavirus" organized on-line by the Association for the Study of Professional Labor Relations on May 13 and 14, 2021.

** PhD, Teaching Assistant, Faculty of Law, University of Bucharest. Judge - Bucharest District 2 Court.

${ }_{1}^{1}$ Published in the Official Gazette, Part I, no. 212/16.03.2020

${ }^{2}$ Published in the Official Gazette, Part I, no. 311/14.04.2020
} 
Law no.319/2006 on safety and health at work ${ }^{3}$, together with the Government Decision no.355/2007 regarding the surveillance of the workers' health ${ }^{4}$ appeared as perfectible facing the magnitude of the situation. As a rule, surveillance of workers' health is provided by occupational medicine specialists ${ }^{5}$, but in the contemporary institutional architecture, public health institutions were included, with a multitude of prerogatives, also among the granting of medical leave.

\section{The nature of medical leave as regulated in Romanian legislation}

By Emergency Ordinance of the Government no. 158/2005 on leave and social health insurance benefits ${ }^{6}$, the Romanian legislator established the categories of people entitled to benefit from medical leave and social health insurance and the conditions under which they may be granted ${ }^{7}$.

According to art.2, paragraph 1 of the previously quoted normative act, it ensures the entitlement to sick leave and related benefits for: a) temporary incapacity for work, insofar as it was caused by common illness or accidents outside work, b) prevention of illness and recovery of work capacity only if they were caused by work accidents or occupational diseases, c) maternity, d) care of the sick child and e) maternal risk.

For the purpose of this paper, the situations indicated in letters a) and b) are relevant.

Given the previously quoted provisions, we note that the purpose envisaged by the legislator in granting medical leave to an insured person is to restore its work capacity, diminished by various ailments or conditions, which determines a high degree of risk for the worker if he is forced to actually perform its activity at work. Even with regard to medical leave for childcare, we notice that the exercise of professional duties would be illusory if the employee had to provide care simultaneously to a minor in a real state of need.

Therefore, as a precondition for granting sick leave, the insured person must be in an objective impossibility to perform professional duties. We consider that this impossibility should be analyzed in concrete terms, starting from the particularities of each case, as an incapacity resulting from an accident may prevent a construction worker from practicing his profession, while a commercial or artistic worker as victim of a comparable accident, would not be affected in any way professionally.

An interesting problem arises for an employee who has two jobs in different areas of activity, working for different employers, for example in education and also in the judiciary. In this case, if the insured suffers an incapacity that requires rest at home,

\footnotetext{
${ }^{3}$ Published in the Official Gazette, Part I, no. 646/27.06.2006

${ }^{4}$ Published in the Official Gazette, Part I, no. 332/17.05.2007

${ }^{5} \mathrm{D}$. Țop - Considerations regarding the supervision of workers' health (original title: Considerații cu privire

la supravegherea sănătății lucrătorilor), Romanian Journal of Labor Law, no.1/2008, pg.60

${ }^{6}$ Published in the Official Gazette, Part I, no. 1074 / 29.11.2005

${ }^{7}$ According to art. 1, 3 and 31 of GEO no. 158/2005
} 
then he will be unable to perform the activity for both employers. If one of the activities can be performed in the form of telework, we consider that the employee is entitled to sick leave only for the activity that he cannot actually carry out.

Telework or "remote working" can be found in Romanian legislation, namely, Law no. 81/2018 on the regulation of telework activity ${ }^{8}$. The term is defined according to art.2, letter a of the law as: "the form of work organization through which the employee, regularly and voluntarily, fulfills his attributions specific to its position, occupation or profession, in another place than the workplace organized by the employer, at least one day a month, using information and communication technology".

We appreciate that the activity of telework is not, de plano, incompatible with the right to sick leave, given that the assessment of the degree of impairment of work capacity must be made in concrete terms, so that a person may be affected by a common illness or occupational disease up to the level at which he could not perform his professional duties neither at work nor elsewhere, even by electronic means.

For public sector employees, the sphere of work performed at home seemed to be a fantasy before the current Sars-CoV-2 pandemic, being imagined, more, as a time of rest than as a way of carrying out the activity.

In recent literature ${ }^{9}$, it was shown that even in the public administration sector it is possible to organize part of the activity in the form of telework, but this encounters difficulties both socially and logistically.

Next, in order to determine the nature of sick leave in current regulations, we take into account that the leave is granted in order to protect the insured person, who is in a state of vulnerability, whose health would be affected if he wouldn't benefit from a period of restoration of work capacity. Exceptionally, medical leave granted to an employee may also protect other people, such as work-colleagues, if the incapacity was caused by an infectious-contagious disease which is likely to be transmitted in communities.

The issue of a medical leave certificate can be done by "any doctor in a contractual relationship with the health insurance companies, as well as by any other doctor with a valid free practice authorization, family doctor or specialist, who concludes an agreement in this regard with health insurance companies (...) or by the health insurance companies for the situations provided in the Government Emergency Ordinance no. 158/2005 on leave and social health insurance benefits", as stipulated in art. 1 of the instructions for 2020 on the use and completion of medical leave certificates, issued by the Ministry of Health ${ }^{10}$.

Specifically, the doctor will decide on the issuance of the certificate after identifying by its own senses, the symptoms that determine the inability of the

\footnotetext{
${ }^{8}$ Published in the Official Gazette, Part I, no. 296 / 02.04.2018

9 L.M.Dima - Telework in the public sector in Romania, an exceptional measure that needs to become the rule? (original title: Telemunca în sectorul public din România, o măsură excepţională care se impune a deveni regulă?), in Romanian Journal of Jurisprudence, no.4/2020, pg.305

${ }^{10}$ Published in the Official Gazette, Part I, no. 583/ 02.07.2020
} 
employee to perform its activity. Both the family doctor and the specialist doctor have the possibility to request the insured person to carry out additional medical investigations, and the granting of the leave will be based on their result.

\section{Peculiarities of medical leave in case of Sars-CoV-2 infection}

An atypical situation is determined by the granting of medical leave in case of infection with Sars-CoV-2 virus.

By Law no. 136/2020 on the establishment of measures in the field of public health in situations of epidemiological and biological risk ${ }^{11}$, exceptional protection measures have been taken, in order to protect the population in the epidemiological context of Sars-CoV-2 virus infection, hereinafter referred to as Covid-19.

By art.3, letter a of Law no.136/2020 quarantine of persons was defined as follows: "measure to prevent the spread of infectious diseases, consisting in the physical separation of persons suspected of being infected or carrying a highly pathogenic agent from other persons, in spaces specially designated by the authorities, at home or at another location declared by the quarantined person, determined by an individual reasoned decision of the Public Health Directorate, which shall contain information on the date and issuer of the act, the name and identification data of the quarantined person, duration the measure and the remedy provided by law". The isolation of a person was defined by art. 3, letter $\mathrm{c}$ of the same normative act as: "a measure consisting in the physical separation of persons affected by an infectious disease or persons carrying the highly pathogenic agent, even if they do not show suggestive signs and symptoms, at home, at the location declared by the isolated person, in a health facility or at an alternative location attached to the health establishment, with a view to monitoring the state of health and the application of treatment, as appropriate, measure established for the purpose of healing and reducing the degree of contagion on the basis of the consent of persons or, lacking that, by reasoned individual decision of the Directorate of Public Health, which shall contain in particular the date and issuer of the act, the name and identification details of the isolated person, the duration of the measure and the appeal provided for by law".

As can be seen from the content of the two protective measures, they imply the impossibility of continuing the activity of the quarantined or isolated person at work, respectively in any other place other than the one where the person will be during the measure, which is an equivalent of an inability to work, determined by medical or epidemiological reasons.

Article 20, paragraph 1 of Law no. 136/2020 recognizes the possibility of granting medical leave for persons in quarantine or isolation, at the time of entry into force of the law. Therefore, until the adoption of these special regulations, obtaining

${ }^{11}$ Published in the Official Gazette, Part I, no. 884 / 28.09.2020 
the medical leave for quarantined or isolated persons was possible in the conditions of G.E.O. no. 158/2005.

By the provisions of art.20, paragraph 2 of Law no.136/2020, it was stipulated that the right to benefit from leave and an indemnity for quarantine is granted to the insured person who is forbidden to continue the activity that could not be performed from home, on the background of the suspicion of infection with a contagious disease, for the period established by the certificate issued by the public health directorate. As a consequence, if the work can be performed by the insured person from home, including by telework, then he will not be entitled to quarantine allowance, having the possibility to work remotely.

The provision appears to be difficult to understand, given that subsequent to the infection, the employee's physical and sometimes mental condition is affected, and the performance of work, although possible in an objective sense, cannot be achieved under normal conditions, even if the person in question has access to electronic means of communication. In view of a coherent interpretation of the legal norm, we consider that the meaning of art.20, paragraph 2 of Law no.136/2020 is to grant the quarantine allowance if the work is not actually performed from home, not only in cases in which the performance of work from home is not objectively possible.

The certificate issued by the public health directorate is defined by art.7, paragraph 2 of the Order of the Minister of Health no.1309/2020 on the manner of application of measures to prevent and limit diseases with Sars-CoV-2 $2^{12}$ as "the quarantine confirmation decision and the isolation confirmation or extension decisions".

As a consequence, the medical leave is still granted by the attending physician ${ }^{13}$, regardless of whether it is the family doctor or the specialist doctor who treats the insured, without ascertaining the symptoms directly by the medical staff, but only on the basis of a decision confirming quarantine, or isolation issued by the public health directorate.

In addition to the issuance procedure, medical leave for quarantine or isolation has a special nature compared to sick leave for incapacity for work, as the duration of such sick leave is not cumulative and the leave due to epidemiological restrictions does not require special medical approval for a period longer than 90 days ${ }^{14}$.

In short, we can appreciate that both forms of medical leave involve the suspension of the individual employment contract during them, under the conditions of art. 50 of the Labor Code $^{15}$, but for different reasons and until the recovery of the employee and of its work capacity ${ }^{16}$.

\footnotetext{
12 Published in the Official Gazette, Part I, no. 642 / 22.07.2020

${ }^{13}$ Under the conditions of art.20, paragraph 3 of Law no.136 / 2020

${ }^{14}$ As it results from the provisions of art. 20, paragraphs 5 and 6 of Law no. 136/2020

${ }^{15}$ Law no. 53/2003 on the Labor Code, with subsequent amendments and completions, republished in the Official Gazette, Part I, no.345/18.05.2011

${ }^{16}$ Al.Țiclea - Labor Code commented, (original title: Codul muncii comentat) 6th edition, Universul Juridic Publishing House, Bucharest, 2015, pg.85
} 
In order to determine the particularities of the medical leave for quarantine or isolation, determined by the Covid-19 infection, as it results from current legislation, we consider that the analysis of three hypothetical situations is necessary:

(i) The insured person is infected, fact confirmed by a positive RT-PCR method test.

In this case, the infected person, regardless of the symptoms of the disease, must be separated from the work environment or restrained in contact with other members of the community to prevent contamination.

Thus, unlike the typical situation of the medical leave for incapacity for work, which aims at protecting the employee, this leave aims at protecting the community, respectively the other employees. Depending on where the infected person is quarantined or isolated, roommates will be at risk of infection if they have not already been contaminated. In this case, the family members have the right, in their turn, to isolation or quarantine, under the conditions of art.1, paragraph 3, letters c and $d$ of the Order of the Minister of Health no.414/2020 regarding the establishment of the quarantine measure for persons in an international public health emergency caused by COVID-19 infection and establishing measures to prevent and limit the effects of the epidemic ${ }^{17}$.

Therefore, in this first case, the insured person has the possibility to benefit from the indemnity leave for either quarantine or isolation, and indirectly affected family members, as co-roommates, to the extent that they are entitled to the social benefit, enjoy the same rights.

(ii) The insured person was in direct contact with a person found positive after the RT-PCR test.

In this situation, the insured person has the obligation to isolate in a place communicated to the public health directorate, where the compliance to the measure will be verified by public order officials.

The insured person has the obligation of quarantine according to art.2, paragraph 1, letter a of the Order of the Minister of Health no.1309/2020, and during the quarantine he is entitled to medical leave under the conditions of art.7 of the same normative act. Given the nature of the measure, it aims to protect both the insured and the members of the community with whom he or she normally interacts. The vulnerable people after taking this measure will be the roommates, mainly composed of family members.

In this situation, we identify an important mismatch. As long as the employee is a direct contact of an infected person, the members of his family, presumably roommates, have the obligation to isolate, according to art.1, paragraph 3, letter $\mathrm{d}$ of the Order of the Minister of Health no.414/11.03.2020, having, consequently, the right to obtain social benefits. If there are other people in the same home, roommates, but outside the family (such as people living in dormitories and sharing the same room), cannot be included in the provisions of article 1, paragraph 3 of Order of the Minister of Health no.414/11.03.2020, thus not benefiting from medical leave and

${ }^{17}$ Published in the Official Gazette, Part I, no. 201/12.03.2020 
the related allowance, although, from an epidemiological point of view, they present a similar risk of contagion with family members.

In order for the protective measures to be effective, we consider that the notion of "family members" must be understood in a broad sense, by including all people living together, in the same housing unit, regardless of the existence of a kinship between them, fact that would allow the granting of medical leave even to roommates.

If the person tested positive is a minor, he or she will be isolated at the home of the tutors or in a location indicated by the tutor. Alternatively, the minor can be isolated in a health unit. Regardless of the situation, "the minor's tutor is subject to the quarantine measure (...), if the measure of isolation does not apply to him", as expressly stipulated in art. 4, paragraph 9, final thesis of Order of the Minister of Health no. 1309/2020.

We notice that the legislator introduced a new terminology, that of "tutor", which cannot be considered identical, in terms of meaning, with the notion of family member or with the notion of roommate. In the absence of a definition of the term used, the degree of uncertainty in understanding and applying the rule is very high.

We also appreciate that the tutor, predictably, is a family member. To the extent that he has made contact with the minor, the solution of isolation or quarantine is natural, however, if the tutor did not come into direct contact with the child in the last 14 days before taking the measure (for example, the child was in another city, where he attended school, living in the dormitory of the educational unit), the obligation to quarantine of the tutor appears meaningless. In addition, the only rational interpretation of article 4, paragraph 9, final thesis of Order of the Minister of Health no.1309/2020 would be that the tutor must isolate or quarantine himself, together with the minor, if the latter cannot support itself alone, therefore, the presence of an adult is required. In this case, the adult concerned shall be entitled to sick leave and the allowance.

(iii) The family member of the insured person is in direct contact with a person positively detected following the RT-PCR test.

An atypical situation is determined by the case when the minor child, usually school or preschool, becomes a direct contact of an infected person and has the obligation to quarantine, under the conditions of art.2, paragraph 1, letter a of Order of the Minister of Health no.1309/2020. Regardless of whether the minor's age allows him to support himself, his family members have the obligation of isolation together with him, under the conditions of art.1, paragraph 3, letter $\mathrm{d}$ of the Order of the Minister of Health no.414/11.03.2020.

In this case, the provisions of art.4, paragraph 9 of Order of the Minister of Health no.1309/2020 cannot be applied by similarity, because minor was not found positive for Covid-19 infection, it was only a contact of a positive tested person.

Assuming that the minor is not employed, his parents will be entitled to obtain medical leave for quarantine, respectively isolation as long as they cannot perform their activity through telework. 
A large problem in practice was determined by the timing of the institutions involved in the process of granting sick leave for epidemiological reasons.

Although the deadlines stipulated for the Public Health Directorate for issuing the decision of quarantine or isolation were short, being set by hours, given the large number of positively confirmed cases, the activity of the directorates was blocked. This fact determined delays of weeks in issuing decisions. In their absence, the attending physician wasn't able to issue the medical leave certificate for quarantine or isolation, which led to extremely difficult practical situations.

Alternative measures given the lack of the decision, are represented by the employee's request for days of rest leave, or unpaid leave, both measures being likely to harm the employee's interests. In addition, although the medical leave certificate can be issued until the end of the month or even the following month ${ }^{18}$, in practice, this proves useless, given that certain activities, especially in the budgetary sector, involve permanent planning and the activity cannot be carried out with another person, in the absence of a formal justification for the absence of the rightful holder.

\section{Conclusions}

Overall, one can observe that contemporary society has been subjected to a very large number of challenges with the declaration of the Covid-19 pandemic by the World Health Organization on 11.03.2020. The medical consequences of the infection were doubled by unpredictable social consequences, to which states have adapted with varying degrees of success.

For the purpose of this paper, we believe that the Romanian legislator, with minor imperfections, has managed to ensure consistent protection of the rights of insured persons by building a functional legislative framework for granting sick leave and benefits in case of infection with Sars-CoV-2 virus.

Moreover, the problems identified during the analysis come from noncorrelations of the normative acts of tertiary character, which have undergone repeated modifications with the evolution of the socio-economic context.

The main benefits of this experience seem to consist of rethinking the way of working at the workplace or at home, together with the change in the relationship between working time and rest time, respectively between incapacity for work and work, but in a remote mode.

In these conditions, the right to sick leave for infected or suspected infected people has lost, in part, its role as an individual right, with the main purpose of protecting the employee, and became a right of the community, with the main purpose of preventing the spread of the virus and ensuring public health.

${ }^{18}$ As it results from the provisions of art.20, paragraph 4 of Law no.136/2020 